\title{
EFFECT OF MAXILLARY OBTURATOR ON QUALITY OF LIFE IN PATIENTS AFTER MAXILLARY RESECTION
}

\author{
Marwa Kothayer ${ }^{*}$ and Ahmed Mostafa Abdelfattah**
}

\begin{abstract}
Aim: The aim of this study was to assess quality of life of patient with maxillectomy after wearing maxillary obturators using the Obturator Functioning Scale (OFS).

Methodology: Fourty patients who underwent surgical resection of the maxilla were selected, randomized into two groups. In one group, the patients were rehabilitated with a maxillary obturator that was having a silicone bulb while in the second group, they received a conventional maxillary obturator with an acrylic bulb. A questionnaire that included the indices of the Obturator Functioning Scale (OFS) was used to evaluate the functional rehabilitation of patients in the study as it was given twice to each patient; one time before fabrication of the obturator and the second time after its construction.
\end{abstract}

Results: obturator fabrication resulted in significant improvement of all the domains of the obturator functioning scale questionnaire in each group. However, on comparing the effect of both types of the obturator on the quality of life, there was no statistical significance.

Conclusion: within limitation of this study, quality of life in patients after maxillary resection could be improved using maxillary obturators

KEYWORDS: Obturator functionning scale, quality of life, silicone bulb, maxillary obturators

\section{INTRODUCTION}

The most common line of treatment for patients with a maxillary tumor is surgical removal of the tumor. This most probably will leave an oronasal and/or oroantral defect, resulting in problems in the functions of mastication, deglutition, and speech. To restore these functions an appropriate replacement of the lost tissue should be done. ${ }^{(1: 3)}$

Functional rehabilitation and quality of life (QOL) after maxillectomy depends on outcomes of maxillofacial reconstruction, the defect size and location, remaining teeth, available soft tissue

\footnotetext{
* Lecturer of Oral and Maxillofacial Prosthodontics, Faculty of Dentistry, Ain Shams University, Cairo, Egypt

** Lecturer of Oral and Maxillofacial Prosthodontics, Faculty of Dentistry, Ain shams University, Cairo, Egypt. Assistant Professor of Oral and Maxillofacial Prosthodontics, College of Dentistry, Taibah University, Al-Madinah Al-Munawarah, Saudi Arabia
} 
undercuts, muscular control and retention of obturator prostheses. ${ }^{(4)}$

Prosthetic obturator was the first method employed in rehabilitating large maxillary defects. It helps to close the defect, support the facial profile, separate the oral and nasal cavities and thus prevent hypernasal speech, nasal regurgitation of food and liquids. ${ }^{(4,5)}$

Polymethylmethacrylate (PMMA) obturator bulbs are relatively hard and non-resilient. The relief for these obturators reduces the retention available for these bulbs and might limit mastication on the resection side. Resilient liners may improve oral functions by enhancing the retention and adapatation with defect tissue. ${ }^{(8)}$

A suitable way for achieving combination of both materials in a resource-challenged setting is by using a resilient silicone bulb over the acrylic. The silicone bulb has been known to enhance retention, stability, and function in obturator prostheses and have a useful service life of three to five years. ${ }^{(9)}$

The Obturator Functioning Scale (OFS) ${ }^{(10)}$ was developed at Memorial Sloan Kettering Cancer Center (New York;NY; USA) as a method of assessing self-reported function of an obturator. It was designed to evaluate eating ability, speech, and cosmetic satisfaction. To rate the items a 5-point Likert scale was used ('not at all', 'a little difficult', 'somewhat difficult', 'very difficult', 'extremely difficult'). For analysis, the responses were were coded from 1 for 'not at all' to 5 for 'extremely difficult'. (10)

So, the objective of this study was to assess the effect of wearing maxillary obturators with a silicone bulb compared to acrylic bulb obturators on quality of life in patients who undergone maxillary resection surgery using the Obturator Functioning Scale (OFS).

\section{MATERIAL AND METHODS}

\section{Patient Selection:}

Fourty patients were selected to share in this study from the outpatient clinic of Prosthodontics Department, Faculty of Dentistry, Ain-Shams University. MedCalc ${ }^{\circledR}$ version 12.3.0.0 program "Ostend, Belgium" was used for calculations of sample size. Statistical calculator was based on 95\% confidence interval and power of the study $80 \%$ with $\alpha$ error $5 \%$. According to a previous study (Ikusika et al., 2016), showed that the mean of chewing scores for an obturator relined with Silicone based resilient-liner was $12.08 \pm 2.78$ in comparison to that of conventional PMMA obturator at $3.67 \pm 3.82$, using paired t test, with p-value $<0.001$ being significant. So it was relied upon in this study. Based on this assumption, sample size was calculated according to these values producing a minimal sample size of 38 cases being enough to find such a difference. Assuming a drop-out ratio of $5 \%$, the sample size was designed to be 40 cases, subdivided into two groups; group I $(n=20)$ in which patients received an obturator with a Silicone bulb and group II $(n=20)$ in which patients received a conventional obturator having regular acrylic bulb. Randomization was guided by a computer generated list. The Silicone bulb group and Acrylic bulb group were placed in 40 numbered closed envelopes according to the computer generated list of random numbers and an envelope was allocated to each patient. Double blinding was done by one of the postgraduate students who was the only one to know the key so that the authors and the patients didnot know in which group is the patient. Afterwards, the authors were informed by the randomization to be tabulated.

\section{Inclusion criteria:}

- Adult patients of both sexes.

- Age range from 18 to 65 years old. 
- A maxillectomy defect patients with at least 4 adjacent teeth.

- The maxillectomy defects $>6$ months old

- Good periodontal condition of the remaining teeth especially the abutment teeth and the terminal abutment close to the defect with no signs of clinical mobility, attachment loss or dehiscence.

- Defects following Brown's classification class IIA

\section{Exclusion criteria:}

- Patients with underlying signs of tumor recurrence.

- Patients with mental instability.

- Patients with history of radiotherapy.

- Trismus; severe degree of trismus with jaw opening reduced to $15 \mathrm{~mm}$ or less

\section{Patient's approval:}

The methodology was reviewed by Faculty of Dentistry Ain-Shams University Research Ethics Committee (FDASUREC). All patients were informed in details about the nature of investigation and the aim of the study. They signed an informed consent form. Patients' data were kept safe and confidential to protect the security and privacy of the patient information. All participants were given notice about their privacy and their rights. All patients were informed about their benefits from research that was obtaining a well-fitting and retentive obturator. All data were kept confidential.

\section{Patient evaluation:}

Accurate personal, medical, and dental history were taken from all patients through a direct interview and questionnaire sheet. Patients were asked about previous history of receiving an obturator and radiotherapy. Extra-oral and intra-oral clinical examinations were done.

\section{Clinical steps}

For the obturator fabrication, irreversible hydrocolloid impressions (Cavex CA37, Netherlands) were made for the maxillary arch after blocking undesirable undercuts with vaselinized gauze. (fig.1), Diagnostic casts were poured and custom made trays were fabricated. The maxillary diagnostic casts were also surveyed to determine the needed teeth preparation. Mandibular impressions were also made and poured.

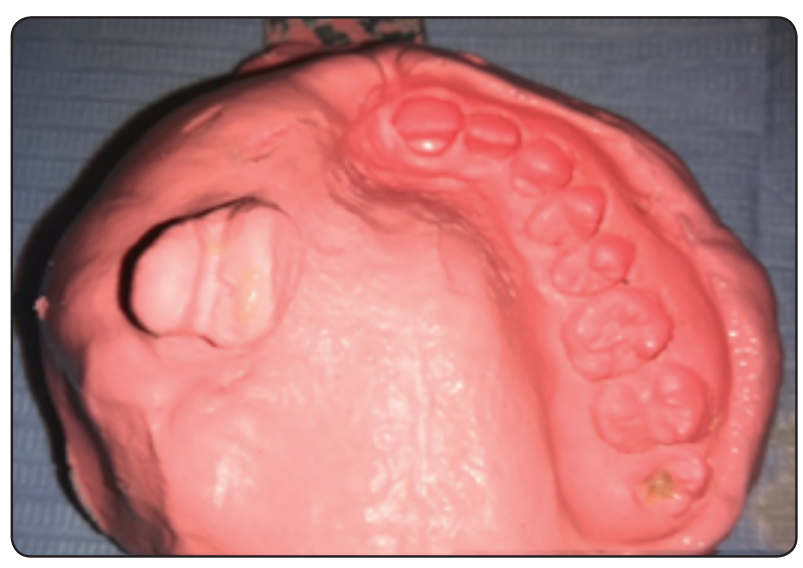

Fig. (1) primary impression using alginate impression material

For fabrication of silicone bulb in group I, a putty index was made for the undercuts present in the defect in the maxillary cast. The cast was then sawed to remove the putty index from the undercuts without tearing. The putty index was then duplicated so as to get a wax duplicate for the putty index. The wax duplicate was then flasked and wax elimination was then done (fig.2). After deflasking, an undercut was made along the inner circumference of the hub to retain the acrylic maxillary obturator with the silicone bulb later. Heat cured silicone material (Molloplast B Detax Gmbh \& Co. Germany) was then packed into the flask under pressure and processing then followed. After processing, the silicone bulb was retrieved from the flask (fig. 3), washed and placed in the patient's mouth to verify its seating. After the planned mouth 


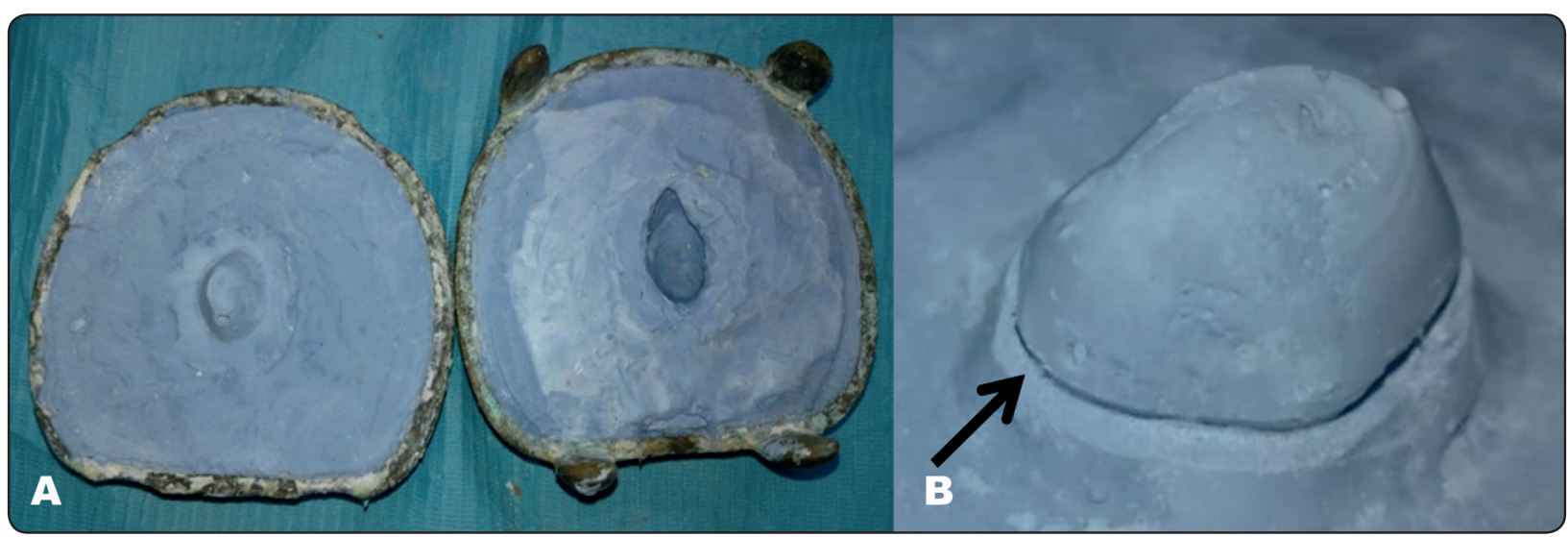

Fig. (2a) upper and lower compartments of the flask after boiling out of the wax pattern of the putty index. Figure 2b: arrow pointing at the undercut made along the circumference of the hub

preparations were done, the silicone bulb was seated in place and secondary impressions using irreversible hydrocolloid were made. The master models were then poured with Type III gypsum material and duplicated to produce the refractory cast for fabrication of the cobalt-chromium metal frameworks for each patient. The frameworks were finished, polished, examined for any roughness or imperfections and then seated in the patient's mouth to verify its fit. Jaw relation registration then followed. For jaw relation registration, auto polymerized acrylic resin record bases were used, the patients were guided into position of centric relation, the casts were mounted and teeth were then arranged. Waxed up try in was then made in the patient's mouth and once verified processing of the maxillary obturator was made. During packing of acrylic resin in the processing stage, hollowing of the obturator was done to reduce its weight. The obturator dentures were then trimmed, finished and polished. The obturators were delivered to the participants. (fig.4). Regarding the fabrication of the conventional PMMA obturator in group II, primary impressions were made as in group I and the study models were poured and surveyed. Mouth preparations were done and secondary impressions were made followed by metal framework fabrication and its evaluation in the patient's mouth. Same steps as in group I of jaw relation registration, waxed-up try in and insertion then followed. The Obturator Functioning Scale ${ }^{(10)} \mathrm{OFS}$ ) developed at Memorial Sloan Kettering Cancer Center (New York, NY, USA) was used as a mean of assessing self-reported functioning of the obturator (table.1.). A 5 points likert scale was used in which the responses were coded from 1 for ("not at all") to 5 for ("extremely difficult"). Each patient filled out the questionnaire of the obturator functioning scale (OFS) before maxillary obturator fabrication and another time after its delivery with three months. Data were recorded for statistical analysis.

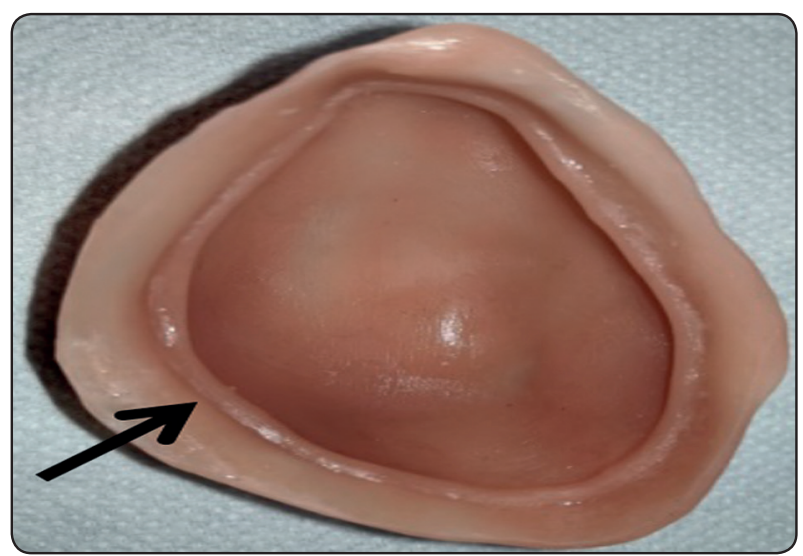

Fig. (3) inner side of the silicone bulb and the arrow showing the retentive lug to engage in the acrylic denture base of the obturator. 


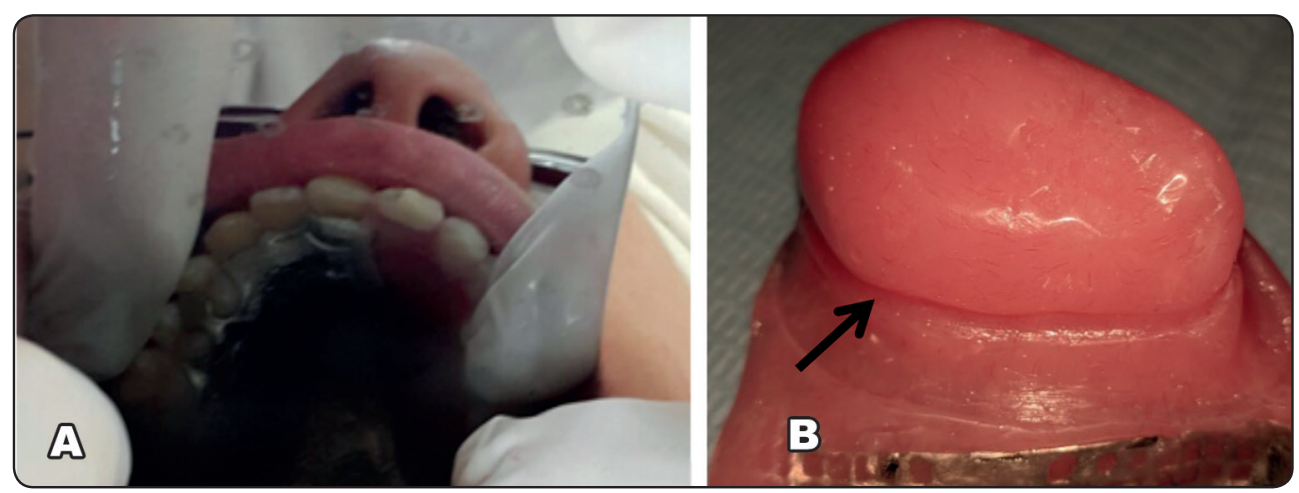

Fig. (4A): insertion of the obturator in the patient's mouth (occlusalview). Fig. (4B) Acrylic part of the obturator with the arrow pointing at the groove that mechanically engages the retentive lug in the silicone bulb

TABLE (1) Obturator functioning scale domains used in the study

\begin{tabular}{|c|c|c|c|c|c|}
\hline Domain $\quad$ Likert scale grade & 1 & 2 & 3 & 4 & 5 \\
\hline \multicolumn{6}{|l|}{ Insertion of obturator } \\
\hline \multicolumn{6}{|l|}{ Speech is understandable } \\
\hline \multicolumn{6}{|l|}{ Nasality of speech } \\
\hline \multicolumn{6}{|l|}{ Pronounciation of words } \\
\hline \multicolumn{6}{|l|}{ Talk in public } \\
\hline \multicolumn{6}{|l|}{ Voice different from before surgery } \\
\hline \multicolumn{6}{|l|}{ Leakage on swallowing fluids } \\
\hline \multicolumn{6}{|l|}{ Leakage on swallowing solids } \\
\hline \multicolumn{6}{|l|}{ Numbness of upper lip } \\
\hline \multicolumn{6}{|l|}{ Upper lip looks funny } \\
\hline \multicolumn{6}{|l|}{ Dryness of the mouth } \\
\hline \multicolumn{6}{|l|}{ Chewing } \\
\hline \multicolumn{6}{|l|}{ Satisfaction with the look } \\
\hline \multicolumn{6}{|l|}{ How noticeable the clasps on anterior teeth } \\
\hline Social/ family interaction & & & & & \\
\hline
\end{tabular}

\section{RESULTS}

The results of the patients' questionnaires were recorded and statistically analysed. Normal distribution of the results were tested and significance level was set at (P-value $<0.05)$ was considered significant. Chisquare, Wilxocon signed rank and Mannwhitney tests were used in this study. Wilxocon was used as a test for non parametric data; within the same group pre and post while Mann-whitney test was used for non parametric data between both groups. Chisquare was used to compare proportions between qualitative data.

The results of group I for the scores of OFS are shown in table $(2,3) .50 \%$ of the patients reported no difficulty regarding insertion of the obturator and $40 \%$ reported little difficulty. As for the speech, $40 \%$ 
of the patients described it to be understandable in the presence of the obturator in comparison to $10 \%$ only of the patients who reported understandable speech before the obturator. On the other hand, $20 \%$ of the sample reported their speech being extremely difficult to be understood before wearing the obturator. Similarily, $60 \%$ of the patients had no nasality in speech after using their obturators in contrast to $20 \%$ of the patients who reported no nasality in speech before obturator fabrication.

$60 \%$ of the patients mentioned no problem at all during pronounciation of words while wearing their obturators however, $20 \%$ only of the sample reported no problem at all during pronounciation before obturator fabrication. Moreover, 50\% of the sample were able to talk in public with no problem at all while wearing their obturators in comparison to $10 \%$ of the sample being able to talk in public freely and $60 \%$ complaining of difficulty talking in public before obturator fabrication. $70 \%$ of the sample found their voice during wearing the obturator not different from before maxillary resection in comparison to $10 \%$ with no difference before obturator fabrication. $50 \%$ of the sample reported no leakage at all during swallowing fluids or solid food while using their obturator in contrast to $20 \%$ with no leakage of fluids and $30 \%$ with no leakage of solid food before obturator fabrication.
Regarding numbness of upper lip, $75 \%$ of the patients stated that there was no numbness at all after using the obturator and $50 \%$ also reported no numbness after the surgery and before obturator fabrication. After wearing the obturator, none of the patients was annoyed with the upper lip appearance in contrast to $30 \%$ of the patients who were annoyed with the appearance of the upper lip before obturator fabrication.

Although none of the patients reported a dry mouth after obturator fabrication, $30 \%$ of the patients stated their mouth to be dry after maxillary resection. After using the obturator, $40 \%$ of the patients described their chewing activity to be easy with no difficulties at all in comparison to $10 \%$ only of the patients with no difficulty in chewing before obturator fabrication. Regarding the look, $50 \%$ of the patients were satisfied after wearing the obturator in comparison to $10 \%$ only who were satisfied before obturator fabrication. The clasps of the obturator were stated to be noticeable by $20 \%$ of the patients in comparison to $30 \%$ of them who found the clasps not to be noticeable at all. The maxillary obturator helped $50 \%$ of the patients with social interaction without any problems at all and $50 \%$ with little problems. On the other hand, $10 \%$ of the patients only were able to interact socially before obturator fabrication.

TABLE (2): Percentage of obturator functioning scale domains in group I before and after obturator fabrication.

\begin{tabular}{|c|c|c|c|c|c|c|}
\hline & & Pre & Post & Test value & P-value & Sig. \\
\hline Insertion of obturator & $\begin{array}{l}\text { 1.not at all } \\
\text { 2.a little difficult } \\
\text { 3.somehow difficult } \\
\text { 4.very difficult } \\
\text { 5.Extremely difficult }\end{array}$ & $\begin{array}{l}- \\
- \\
- \\
- \\
-\end{array}$ & $\begin{array}{c}10(50.0 \%) \\
8(40.0 \%) \\
2(10.0 \%) \\
0(0.0 \%) \\
0(0.0 \%)\end{array}$ & - & - & - \\
\hline Speech is understandable & $\begin{array}{l}\text { 1.not at all } \\
\text { 2.a little difficult } \\
\text { 3.somehow difficult } \\
\text { 4.very difficult } \\
\text { 5.Extremely difficult }\end{array}$ & $\begin{array}{l}2(10.0 \%) \\
2(10.0 \%) \\
7(35.0 \%) \\
5(25.0 \%) \\
4(20.0 \%)\end{array}$ & $\begin{array}{c}8(40.0 \%) \\
6(30.0 \%) \\
6(30.0 \%) \\
0(0.0 \%) \\
0(0.0 \%)\end{array}$ & 14.677 & 0.005 & $S$ \\
\hline
\end{tabular}




\begin{tabular}{|c|c|c|c|c|c|c|}
\hline & & Pre & Post & Test value & P-value & Sig. \\
\hline Nasality of speech & $\begin{array}{l}\text { 1.not at all } \\
\text { 2.a little difficult } \\
\text { 3.somehow difficult } \\
\text { 4.very difficult } \\
\text { 5.Extremely difficult }\end{array}$ & $\begin{array}{l}4(20.0 \%) \\
4(20.0 \%) \\
4(20.0 \%) \\
3(15.0 \%) \\
5(25.0 \%)\end{array}$ & $\begin{array}{c}12(60.0 \%) \\
4(20.0 \%) \\
4(20.0 \%) \\
0(0.0 \%) \\
0(0.0 \%) \\
\end{array}$ & 12.000 & 0.017 & $\mathrm{~S}$ \\
\hline Pronounciation of words & $\begin{array}{l}\text { 1.not at all } \\
\text { 2.a little difficult } \\
\text { 3.somehow difficult } \\
\text { 4.very difficult } \\
\text { 5.Extremely difficult }\end{array}$ & $\begin{array}{c}4(20.0 \%) \\
0(0.0 \%) \\
9(45.0 \%) \\
3(15.0 \%) \\
4(20.0 \%) \\
\end{array}$ & $\begin{array}{c}12(60.0 \%) \\
6(30.0 \%) \\
2(10.0 \%) \\
0(0.0 \%) \\
0(0.0 \%) \\
\end{array}$ & 21.455 & 0.000 & $S$ \\
\hline Talk in public & $\begin{array}{l}\text { 1.not at all } \\
\text { 2.a little difficult } \\
\text { 3.somehow difficult } \\
\text { 4.very difficult } \\
\text { 5.Extremely difficult }\end{array}$ & $\begin{array}{l}2(10.0 \%) \\
2(10.0 \%) \\
4(20.0 \%) \\
7(35.0 \%) \\
5(25.0 \%) \\
\end{array}$ & $\begin{array}{c}10(50.0 \%) \\
6(30.0 \%) \\
4(20.0 \%) \\
0(0.0 \%) \\
0(0.0 \%) \\
\end{array}$ & 19.333 & 0.001 & S \\
\hline $\begin{array}{l}\text { Voice different from } \\
\text { before surgery }\end{array}$ & $\begin{array}{l}\text { 1.not at all } \\
\text { 2.a little difficult } \\
\text { 3.somehow difficult } \\
\text { 4.very difficult } \\
\text { 5.Extremely difficult }\end{array}$ & $\begin{array}{c}2(10.0 \%) \\
4(20.0 \%) \\
5(25.0 \%) \\
1(5.0 \%) \\
8(40.0 \%) \\
\end{array}$ & $\begin{array}{c}14(70.0 \%) \\
3(15.0 \%) \\
3(15.0 \%) \\
0(0.0 \%) \\
0(0.0 \%) \\
\end{array}$ & 18.643 & 0.001 & $S$ \\
\hline $\begin{array}{l}\text { Leakage on } \\
\text { swallowing fluids }\end{array}$ & $\begin{array}{l}\text { 1.not at all } \\
\text { 2.a little difficult } \\
\text { 3.somehow difficult } \\
\text { 4.very difficult } \\
\text { 5.Extremely difficult }\end{array}$ & $\begin{array}{c}4(20.0 \%) \\
4(20.0 \%) \\
0(0.0 \%) \\
5(25.0 \%) \\
7(35.0 \%) \\
\end{array}$ & $\begin{array}{c}10(50.0 \%) \\
8(40.0 \%) \\
0(0.0 \%) \\
2(10.0 \%) \\
0(0.0 \%) \\
\end{array}$ & 12.190 & 0.007 & S \\
\hline $\begin{array}{l}\text { Leakage on } \\
\text { swallowing solids }\end{array}$ & $\begin{array}{l}\text { 1.not at all } \\
\text { 2.a little difficult } \\
\text { 3.somehow difficult } \\
\text { 4.very difficult } \\
\text { 5.Extremely difficult }\end{array}$ & $\begin{array}{l}6(30.0 \%) \\
4(20.0 \%) \\
3(15.0 \%) \\
2(10.0 \%) \\
5(25.0 \%) \\
\end{array}$ & $\begin{array}{c}10(50.0 \%) \\
8(40.0 \%) \\
2(10.0 \%) \\
0(0.0 \%) \\
0(0.0 \%) \\
\end{array}$ & 9.533 & 0.049 & $S$ \\
\hline Numbness of upper lip & $\begin{array}{l}\text { 1.not at all } \\
\text { 2.a little difficult } \\
\text { 3.somehow difficult } \\
\text { 4.very difficult } \\
\text { 5.Extremely difficult }\end{array}$ & $\begin{array}{c}10(50.0 \%) \\
3(15.0 \%) \\
3(15.0 \%) \\
0(0.0 \%) \\
4(20.0 \%) \\
\end{array}$ & $\begin{array}{c}15(75.0 \%) \\
5(25.0 \%) \\
0(0.0 \%) \\
0(0.0 \%) \\
0(0.0 \%) \\
\end{array}$ & 8.500 & 0.037 & $\mathrm{~S}$ \\
\hline Upper lip looks funny & $\begin{array}{l}\text { 1.not at all } \\
\text { 2.a little difficult } \\
\text { 3.somehow difficult } \\
\text { 4.very difficult } \\
\text { 5.Extremely difficult }\end{array}$ & $\begin{array}{c}6(30.0 \%) \\
4(20.0 \%) \\
4(20.0 \%) \\
0(0.0 \%) \\
6(30.0 \%) \\
\end{array}$ & $\begin{array}{c}13(65.0 \%) \\
1(5.0 \%) \\
6(30.0 \%) \\
0(0.0 \%) \\
0(0.0 \%) \\
\end{array}$ & 10.779 & 0.013 & S \\
\hline Dryness of the mouth & $\begin{array}{l}\text { 1.not at all } \\
\text { 2.a little difficult } \\
\text { 3.somehow difficult } \\
\text { 4.very difficult } \\
\text { 5.Extremely difficult }\end{array}$ & $\begin{array}{l}6(30.0 \%) \\
8(40.0 \%) \\
0(0.0 \%) \\
0(0.0 \%) \\
6(30.0 \%) \\
\end{array}$ & $\begin{array}{c}13(65.0 \%) \\
5(25.0 \%) \\
2(10.0 \%) \\
0(0.0 \%) \\
0(0.0 \%) \\
\end{array}$ & 11.271 & 0.010 & S \\
\hline Chewing & $\begin{array}{l}\text { 1.not at all } \\
\text { 2.a little difficult } \\
\text { 3.somehow difficult } \\
\text { 4.very difficult } \\
\text { 5.Extremely difficult }\end{array}$ & $\begin{array}{l}2(10.0 \%) \\
2(10.0 \%) \\
3(15.0 \%) \\
7(35.0 \%) \\
6(30.0 \%) \\
\end{array}$ & $\begin{array}{c}8(40.0 \%) \\
6(30.0 \%) \\
0(0.0 \%) \\
4(20.0 \%) \\
2(10.0 \%) \\
\end{array}$ & 11.418 & 0.022 & $\mathrm{~S}$ \\
\hline
\end{tabular}




\begin{tabular}{|c|c|c|c|c|c|c|}
\hline & & Pre & Post & Test value & P-value & Sig. \\
\hline Satisfaction with the look & $\begin{array}{l}\text { 1.not at all } \\
\text { 2.a little difficult } \\
\text { 3.somehow difficult } \\
\text { 4.very difficult } \\
\text { 5.Extremely difficult }\end{array}$ & $\begin{array}{c}2(10.0 \%) \\
2(10.0 \%) \\
0(0.0 \%) \\
7(35.0 \%) \\
9(45.0 \%)\end{array}$ & $\begin{array}{c}10(50.0 \%) \\
8(40.0 \%) \\
0(0.0 \%) \\
2(10.0 \%) \\
0(0.0 \%)\end{array}$ & 20.711 & 0.000 & $S$ \\
\hline $\begin{array}{l}\text { How noticeable the } \\
\text { clasps on anterior teeth }\end{array}$ & $\begin{array}{l}\text { 1.not at all } \\
\text { 2.a little difficult } \\
\text { 3.somehow difficult } \\
\text { 4.very difficult } \\
\text { 5.Extremely difficult }\end{array}$ & $\begin{array}{l}- \\
- \\
- \\
-\end{array}$ & $\begin{array}{c}6(30.0 \%) \\
7(35.0 \%) \\
3(15.0 \%) \\
4(20.0 \%) \\
0(0.0 \%) \\
\end{array}$ & - & - & - \\
\hline Social/ family interaction & $\begin{array}{l}\text { 1.not at all } \\
\text { 2.a little difficult } \\
\text { 3.somehow difficult } \\
\text { 4.very difficult } \\
\text { 5.Extremely difficult }\end{array}$ & $\begin{array}{l}2(10.0 \%) \\
5(25.0 \%) \\
7(35.0 \%) \\
0(0.0 \%) \\
6(30.0 \%)\end{array}$ & $\begin{array}{c}10(50.0 \%) \\
10(50.0 \%) \\
0(0.0 \%) \\
0(0.0 \%) \\
0(0.0 \%)\end{array}$ & 20.000 & 0.000 & $\mathrm{~S}$ \\
\hline
\end{tabular}

The median, quartile, mean and the standard deviation of each domain in OFS are presented in Table 3. The median for speech being understandable was 2 and the mean was $1.9( \pm 0.85)$ after using the obturator while before obturator fabrication the median was 3 and the mean was $3.35( \pm 1.23)$ showing a statistical significance in this domain. Regarding nasality of speech, the median was 3 and the mean was $3.05( \pm 1.50)$ before obturator fabrication and the median was 1 with mean 1.60 $( \pm 0.82)$ following its fabrication, reflecting the statistically significant effect of maxillary obturator on improvement of speech. Similarly, the obturator had a statistically significant effect on improving pronunciation of words as the median before and after obturator fabrication was 3 and 1 respectively and the mean before and after obturator fabrication was $3.15( \pm 1.35)$ and $1.60( \pm 0.82)$ respectively. The fabrication of the obturator had a significant effect on the patients in the study to talk in public; the median for talking in public before the obturator was 4 and the mean was $3.55( \pm 1.28)$ and while wearing the obturator the median was 1.5 and the mean was $1.7( \pm 0.8)$. As for the voice being different from before the maxillary resection the median was 3 and the mean was $3.45( \pm 1.47)$ before obturator fabrication but after obturator fabrication the median was 1 and the mean was $1.45( \pm 0.76)$. Before obturator fabrication, the median for leakage on swallowing fluids was 4 and the mean was $3.35( \pm$ 1.63) and after obturator fabrication the median was 1.5 and the mean was $1.7( \pm 0.92)$. The median for leakage on swallowing solids before obturator fabrication was 2.5 and the mean was $2.8( \pm 1.61)$ and after obturator fabrication the median was 1.5 and the mean was $1.6( \pm 0.68)$. The numbness of upper lip domain had a median 1.5 and a mean $2.8( \pm 1.64)$ before obturator fabrication and a median 1 and a mean 1.25( \pm 0.44$)$ after wearing the obturator. For the upper lip looks funny, the median was 2.5 and the mean was $2.8( \pm 1.64)$ before obturator fabrication while the median was 1 and the mean was $1.65( \pm 0.93)$ after its fabrication. The median for dryness of the mouth was 2 and the mean was 2.6( \pm 1.67$)$ before obturator fabrication and the median was 1 and the mean was $1.45( \pm 0.69)$ while using the obturator. Chewing function had a median 4 and mean 3.65( \pm 1.31$)$ before obturator fabrication and a median 2 and a mean 2.3 $( \pm 1.35)$ following the obturator fabrication. The obturator had a significant effect on the patients' satisfaction with their look as the median without the obturator was 4 and the mean was $3.95( \pm 1.36)$ and with the obturator the median was 1.5 and the mean was $1.7( \pm 0.92)$. The median for social and family interaction was 3 and the mean was $3.15( \pm 1.39)$ before obturator fabrication and after fabrication the median was 1.5 and the mean was $1.5( \pm 0.51)$. 
TABLE (3) Median, quartiles, mean and standard deviation of obturator functioning scale domains in group I before and after obturator fabrication.

\begin{tabular}{|c|c|c|c|c|c|c|}
\hline & & Pre & Post & Test value* & P-value & Sig. \\
\hline Insertion of obturator & $\begin{array}{l}\text { Median(Quartile 25th-75th) } \\
\text { Mean } \pm \text { SD } \\
\text { Range }\end{array}$ & - & $\begin{array}{c}1.5(1-2) \\
1.60 \pm 0.68 \\
1-3\end{array}$ & - & - & - \\
\hline $\begin{array}{l}\text { Speech is } \\
\text { understandable }\end{array}$ & $\begin{array}{l}\text { Median(Quartile 25th-75th) } \\
\text { Mean } \pm \text { SD } \\
\text { Range }\end{array}$ & $\begin{array}{c}3(3-4) \\
3.35 \pm 1.23 \\
1-5\end{array}$ & $\begin{array}{c}2(1-3) \\
1.90 \pm 0.85 \\
1-3\end{array}$ & 4.529 & 0.000 & S \\
\hline Nasality of speech & $\begin{array}{l}\text { Median(Quartile 25th-75th) } \\
\text { Mean } \pm \text { SD } \\
\text { Range }\end{array}$ & $\begin{array}{c}3(2-4.75) \\
3.05 \pm 1.50 \\
1-5\end{array}$ & $\begin{array}{c}1(1-2) \\
1.60 \pm 0.82 \\
1-3\end{array}$ & 4.529 & 0.000 & S \\
\hline $\begin{array}{l}\text { Pronounciation of } \\
\text { words }\end{array}$ & $\begin{array}{l}\text { Median(Quartile 25th-75th) } \\
\text { Mean } \pm \text { SD } \\
\text { Range }\end{array}$ & $\begin{array}{c}3(3-4) \\
3.15 \pm 1.35 \\
1-5\end{array}$ & $\begin{array}{c}1(1-2) \\
1.50 \pm 0.69 \\
1-3\end{array}$ & 4.277 & 0.000 & $S$ \\
\hline Talk in public & $\begin{array}{l}\text { Median(Quartile 25th-75th) } \\
\text { Mean } \pm \text { SD } \\
\text { Range }\end{array}$ & $\begin{array}{c}4(3-4.75) \\
3.55 \pm 1.28 \\
1-5\end{array}$ & $\begin{array}{c}1.5(1-2) \\
1.70 \pm 0.80 \\
1-3\end{array}$ & 8.373 & 0.000 & $S$ \\
\hline $\begin{array}{l}\text { Voice different from } \\
\text { before surgery }\end{array}$ & $\begin{array}{l}\text { Median(Quartile 25th-75th) } \\
\text { Mean } \pm \text { SD } \\
\text { Range }\end{array}$ & $\begin{array}{c}3(2-5) \\
3.45 \pm 1.47 \\
1-5\end{array}$ & $\begin{array}{c}1(1-2) \\
1.45 \pm 0.76 \\
1-3\end{array}$ & 6.164 & 0.000 & S \\
\hline $\begin{array}{l}\text { Leakage on } \\
\text { swallowing fluids }\end{array}$ & $\begin{array}{l}\text { Median(Quartile 25th-75th) } \\
\text { Mean } \pm \text { SD } \\
\text { Range }\end{array}$ & $\begin{array}{c}4(2-5) \\
3.35 \pm 1.63 \\
1-5\end{array}$ & $\begin{array}{c}1.5(1-2) \\
1.70 \pm 0.92 \\
1-4\end{array}$ & 5.180 & 0.000 & $S$ \\
\hline $\begin{array}{l}\text { Leakage on } \\
\text { swallowing solids }\end{array}$ & $\begin{array}{l}\text { Median(Quartile 25th-75th) } \\
\text { Mean } \pm \text { SD } \\
\text { Range }\end{array}$ & $\begin{array}{c}2.5(1-4.75) \\
2.80 \pm 1.61 \\
1-5\end{array}$ & $\begin{array}{c}1.5(1-2) \\
1.60 \pm 0.68 \\
1-3\end{array}$ & 4.660 & 0.000 & $S$ \\
\hline Numbness of upper lip & $\begin{array}{l}\text { Median(Quartile 25th-75th) } \\
\text { Mean } \pm \text { SD } \\
\text { Range }\end{array}$ & $\begin{array}{c}1.5(1-3) \\
2.25 \pm 1.59 \\
1-5\end{array}$ & $\begin{array}{c}1(1-1.75) \\
1.25 \pm 0.44 \\
1-2\end{array}$ & 3.684 & 0.002 & $S$ \\
\hline Upper lip looks funny & $\begin{array}{l}\text { Median(Quartile 25th-75th) } \\
\text { Mean } \pm \text { SD } \\
\text { Range }\end{array}$ & $\begin{array}{c}2.5(1-5) \\
2.80 \pm 1.64 \\
1-5\end{array}$ & $\begin{array}{c}1(1-3) \\
1.65 \pm 0.93 \\
1-3\end{array}$ & 5.510 & 0.000 & $S$ \\
\hline Dryness of the mouth & $\begin{array}{l}\text { Median(Quartile 25th-75th) } \\
\text { Mean } \pm \text { SD } \\
\text { Range }\end{array}$ & $\begin{array}{c}2(1-5) \\
2.60 \pm 1.67 \\
1-5\end{array}$ & $\begin{array}{c}1(1-2) \\
1.45 \pm 0.69 \\
1-3\end{array}$ & 3.217 & 0.005 & $S$ \\
\hline Chewing & $\begin{array}{l}\text { Median(Quartile 25th-75th) } \\
\text { Mean } \pm \text { SD } \\
\text { Range }\end{array}$ & $\begin{array}{c}4(3-5) \\
3.65 \pm 1.31 \\
1-5\end{array}$ & $\begin{array}{c}2(1-4) \\
2.30 \pm 1.46 \\
1-5\end{array}$ & 2.862 & 0.010 & $S$ \\
\hline $\begin{array}{l}\text { Satisfaction with the } \\
\text { look }\end{array}$ & $\begin{array}{l}\text { Median(Quartile 25th-75th) } \\
\text { Mean } \pm \text { SD } \\
\text { Range }\end{array}$ & $\begin{array}{c}4(4-5) \\
3.95 \pm 1.36 \\
1-5\end{array}$ & $\begin{array}{c}1.5(1-2) \\
1.70 \pm 0.92 \\
1-4\end{array}$ & 6.957 & 0.000 & S \\
\hline $\begin{array}{l}\text { How noticeable the } \\
\text { clasps on anterior teeth }\end{array}$ & $\begin{array}{l}\text { Median(Quartile 25th-75th) } \\
\text { Mean } \pm \text { SD } \\
\text { Range }\end{array}$ & $\begin{array}{l}- \\
-\end{array}$ & $\begin{array}{c}2(1-3) \\
2.25 \pm 1.12 \\
1-4\end{array}$ & - & - & - \\
\hline $\begin{array}{l}\text { Social/ family } \\
\text { interaction }\end{array}$ & $\begin{array}{l}\text { Median(Quartile 25th-75th) } \\
\text { Mean } \pm \text { SD } \\
\text { Range }\end{array}$ & $\begin{array}{c}3(2-5) \\
3.15 \pm 1.39 \\
1-5\end{array}$ & $\begin{array}{c}1.5(1-2) \\
1.50 \pm 0.51 \\
1-2\end{array}$ & 5.472 & 0.000 & S \\
\hline
\end{tabular}


The results of group II for the scores of OFS are shown in table $(4,5) .60 \%$ of the patients reported no difficulty regarding insertion of the obturator and $20 \%$ reported little difficulty. As for the speech, $45 \%$ of the patients described it to be understandable in the presence of the obturator in comparison to $5 \%$ only of the patients who reported understandable speech before the obturator. On the other hand, $20 \%$ of the sample reported their speech being extremely difficult to be understood before wearing the obturator. Similarily, $60 \%$ of the patients had no nasality in speech after using their obturators in contrast to $20 \%$ of the patients who reported no nasality in speech before obturator fabrication.

$35 \%$ of the patients mentioned no problem at all during pronounciation of words while wearing their obturators however, $25 \%$ only of the sample reported no problem at all during pronounciation before obturator fabrication. Moreover, $45 \%$ of the sample were able to talk in public with no problem at all while wearing their obturators in comparison to $10 \%$ of the sample being able to talk in public freely and $25 \%$ complaining of difficulty talking in public before obturator fabrication. $55 \%$ of the sample found their voice during wearing the obturator not different from before maxillary resection in comparison to $10 \%$ with no difference before obturator fabrication. $40 \%$ of the sample reported no leakage at all during swallowing fluids or solid food while using their obturator in contrast to $15 \%$ with no leakage of fluids and $5 \%$ with no leakage of solid food before obturator fabrication. Regarding numbness of upper lip, $70 \%$ of the patients stated that there was no numbness at all after using the obturator and $55 \%$ also reported no numbness after the surgery and before obturator fabrication. After wearing the obturator, only $10 \%$ the patients were annoyed with the upper lip appearance in contrast to $40 \%$ of the patients who were annoyed with the appearance of the upper lip before obturator fabrication.
Although none of the patients reported a dry mouth after obturator fabrication, $30 \%$ of the patients stated their mouth to be dry after maxillary resection. After using the obturator, $40 \%$ of the patients described their chewing activity to be easy with no difficulties at all in comparison to $10 \%$ only of the patients with no difficulty in chewing before obturator fabrication. Regarding the look, $50 \%$ of the patients were satisfied after wearin $\mathrm{g}$ the obturator in comparison to $5 \%$ only who were satisfied before obturator fabrication. The clasps of the obturator were stated to be noticeable by none of the patients in comparison to $30 \%$ of them who found the clasps not to be noticeable at all. The maxillary obturator helped $50 \%$ of the patients with social interaction without any problems at all and $20 \%$ with little problems. On the other hand, $15 \%$ of the patients only were able to interact socially before obturator fabrication.

The median, quartiles, mean and the standard deviation of each domain in OFS for group II are presented in Table 5. The median for speech being understandable was 2 and the mean was $1.90 \pm 0.97$ after using the obturator while before obturator fabrication the median was 3 and the mean was $3.25 \pm 1.21$ showing a statistical significance in this domain. Regarding nasality of speech, the median was 3 and the mean was $3.0 \pm 1.45$ before obturator fabrication and the median was 1 with mean $1.70 \pm 1.13$ following its fabrication, reflecting the statistically significant effect of maxillary obturator on improvement of speech. Similarly, the obturator had a statistically significant effect on improving pronunciation of words as the median before and after obturator fabrication was 3 and 2 respectively and the mean before and after obturator fabrication was $3.20 \pm 1.54$ and $2.1 \pm 1.17$ respectively. The fabrication of the obturator had a significant effect on the patients in the study to talk in public; the median for talking in public before the obturator was 4 and the mean was $3.55 \pm 1.28$ and while wearing the obturator the median was 2 and the mean was 2 
TABLE (4): Percentage of obturator functioning scale domains in group II before and after obturator fabrication.

\begin{tabular}{|c|c|c|c|c|c|c|}
\hline & & Pre & Post & $\begin{array}{c}\text { Test } \\
\text { value }\end{array}$ & P-value & Sig. \\
\hline Insertion of obturator & $\begin{array}{l}\text { 1.not at all } \\
\text { 2.a little difficult } \\
\text { 3.somehow difficult } \\
\text { 4.very difficult } \\
\text { 5.Extremely difficult }\end{array}$ & $\begin{array}{l}- \\
- \\
- \\
-\end{array}$ & $\begin{array}{c}12(60 \%) \\
4(20 \%) \\
3(15 \%) \\
1(5 \%) \\
0(0 \%) \\
\end{array}$ & - & - & - \\
\hline Speech is understandable & $\begin{array}{l}\text { 1.not at all } \\
\text { 2.a little difficult } \\
\text { 3.somehow difficult } \\
\text { 4.very difficult } \\
\text { 5.Extremely difficult }\end{array}$ & $\begin{array}{l}1(5 \%) \\
5(25 \%) \\
6(30 \%) \\
4(20 \%) \\
4(20 \%) \\
\end{array}$ & $\begin{array}{ll}9 & (45 \%) \\
5 & (25 \%) \\
5 & (25 \%) \\
1 & (5 \%) \\
0 & (0 \%) \\
\end{array}$ & 12.294 & 0.015 & $S$ \\
\hline Nasality of speech & $\begin{array}{l}\text { 1.not at all } \\
\text { 2.a little difficult } \\
\text { 3.somehow difficult } \\
\text { 4.very difficult } \\
\text { 5.Extremely difficult }\end{array}$ & $\begin{array}{l}4(20.0 \%) \\
4(20.0 \%) \\
4(20.0 \%) \\
4(20.0 \%) \\
4(20.0 \%)\end{array}$ & $\begin{array}{l}12(60.0 \%) \\
5(25.0 \%) \\
1(5.0 \%) \\
1(5.0 \%) \\
1(5.0 \%)\end{array}$ & 90511 & 0.04 & $\mathrm{~S}$ \\
\hline Pronounciation of words & $\begin{array}{l}\text { 1.not at all } \\
\text { 2.a little difficult } \\
\text { 3.somehow difficult } \\
\text { 4.very difficult } \\
\text { 5.Extremely difficult }\end{array}$ & $\begin{array}{l}5(25.0 \%) \\
0(0.0 \%) \\
7(35.0 \%) \\
2(10.0 \%) \\
6(30.0 \%) \\
\end{array}$ & $\begin{array}{l}7(35.0 \%) \\
8(40.0 \%) \\
2(10.0 \%) \\
2(10.0 \%) \\
1(5.0 \%)\end{array}$ & 14.683 & 0.0049 & $S$ \\
\hline Talk in public & $\begin{array}{l}\text { 1.not at all } \\
\text { 2.a little difficult } \\
\text { 3.somehow difficult } \\
\text { 4.very difficult } \\
\text { 5.Extremely difficult }\end{array}$ & $\begin{array}{l}2(10.0 \%) \\
2(10.0 \%) \\
4(20.0 \%) \\
7(35.0 \%) \\
5(25.0 \%) \\
\end{array}$ & $\begin{array}{l}9(45.0 \%) \\
6(30.0 \%) \\
2(10.0 \%) \\
2(10.0 \%) \\
1(5.0 \%)\end{array}$ & 19.333 & 0.001 & $\mathrm{~S}$ \\
\hline $\begin{array}{l}\text { Voice different from } \\
\text { before surgery }\end{array}$ & $\begin{array}{l}\text { 1.not at all } \\
\text { 2.a little difficult } \\
\text { 3.somehow difficult } \\
\text { 4.very difficult } \\
\text { 5.Extremely difficult }\end{array}$ & $\begin{array}{l}2(10.0 \%) \\
3(15.0 \%) \\
3(15.0 \%) \\
7(35.0 \%) \\
2(10.0 \%) \\
\end{array}$ & $\begin{array}{l}11(55.0 \%) \\
5(25.0 \%) \\
2(10.0 \%) \\
1(5.0 \%) \\
1(5.0 \%) \\
\end{array}$ & 13.413 & 0.009 & $\mathrm{~S}$ \\
\hline $\begin{array}{l}\text { Leakage on } \\
\text { swallowing fluids }\end{array}$ & $\begin{array}{l}\text { 1.not at all } \\
\text { 2.a little difficult } \\
\text { 3.somehow difficult } \\
\text { 4.very difficult } \\
\text { 5.Extremely difficult }\end{array}$ & $\begin{array}{l}3(15.0 \%) \\
3(15.0 \%) \\
2(10.0 \%) \\
4(20.0 \%) \\
8(40.0 \%)\end{array}$ & $\begin{array}{l}8(40.0 \%) \\
9(45.0 \%) \\
1(5.0 \%) \\
2(10.0 \%) \\
0(0.0 \%)\end{array}$ & 14.273 & 0.007 & $\mathrm{~S}$ \\
\hline $\begin{array}{l}\text { Leakage on } \\
\text { swallowing solids }\end{array}$ & $\begin{array}{l}\text { 1.not at all } \\
\text { 2.a little difficult } \\
\text { 3.somehow difficult } \\
\text { 4.very difficult } \\
\text { 5.Extremely difficult }\end{array}$ & $\begin{array}{l}1(5.0 \%) \\
2(10.0 \%) \\
4(20.0 \%) \\
5(25.0 \%) \\
8(40.0 \%)\end{array}$ & $\begin{array}{l}7(35.0 \%) \\
4(20.0 \%) \\
5(25.0 \%) \\
3(15.0 \%) \\
1(5.0 \%)\end{array}$ & 11.22 & 0.02 & $\mathrm{~S}$ \\
\hline Numbness of upper lip & $\begin{array}{l}\text { 1.not at all } \\
\text { 2.a little difficult } \\
\text { 3.somehow difficult } \\
\text { 4.very difficult } \\
\text { 5.Extremely difficult }\end{array}$ & $\begin{array}{l}11(55.0 \%) \\
1(5.0 \%) \\
4(20.0 \%) \\
2(10.0 \%) \\
2(10.0 \%)\end{array}$ & $\begin{array}{l}14(70.0 \%) \\
4(20.0 \%) \\
2(10.0 \%) \\
0(0.0 \%) \\
0(0.0 \%) \\
\end{array}$ & 4.5 & 0.21 & NS \\
\hline Upper lip looks funny & $\begin{array}{l}\text { 1.not at all } \\
\text { 2.a little difficult } \\
\text { 3.somehow difficult } \\
\text { 4.very difficult } \\
\text { 5.Extremely difficult }\end{array}$ & $\begin{array}{l}1(5.0 \%) \\
2(10.0 \%) \\
5(25.0 \%) \\
4(20.0 \%) \\
8(40.0 \%)\end{array}$ & $\begin{array}{l}10(50.0 \%) \\
5(25.0 \%) \\
2(10.0 \%) \\
1(5.0 \%) \\
2(10.0 \%) \\
\end{array}$ & 15.53 & 0.004 & $S$ \\
\hline Dryness of the mouth & $\begin{array}{l}\text { 1.not at all } \\
\text { 2.a little difficult } \\
\text { 3.somehow difficult } \\
\text { 4.very difficult } \\
\text { 5.Extremely difficult }\end{array}$ & $\begin{array}{l}6(30.0 \%) \\
8(40.0 \%) \\
0(0.0 \%) \\
0(0.0 \%) \\
6(30.0 \%)\end{array}$ & $\begin{array}{l}12(60.0 \%) \\
4(20.0 \%) \\
4(20.0 \%) \\
0(0.0 \%) \\
0(0.0 \%)\end{array}$ & 13.33 & 0.004 & $\mathrm{~S}$ \\
\hline Chewing & $\begin{array}{l}\text { 1.not at all } \\
\text { 2.a little difficult } \\
\text { 3.somehow difficult } \\
\text { 4.very difficult } \\
\text { 5.Extremely difficult }\end{array}$ & $\begin{array}{l}2(10.0 \%) \\
2(10.0 \%) \\
3(15.0 \%) \\
6(30.0 \%) \\
7(35.0 \%)\end{array}$ & $\begin{array}{l}8(40.0 \%) \\
5(25.0 \%) \\
3(15.0 \%) \\
2(10.0 \%) \\
210.0 \%)\end{array}$ & 9.66 & 0.044 & S \\
\hline Satisfaction with the look & $\begin{array}{l}\text { 1.not at all } \\
\text { 3.a little difficult } \\
\text { 4.somehow difficult } \\
\text { 5.Extremely difficult } \\
\end{array}$ & $\begin{array}{l}1(5.0 \%) \\
3(15.0 \%) \\
1(5.0 \%) \\
6(30.0 \%) \\
9(45.0 \%) \\
\end{array}$ & $\begin{array}{c}11(50.0 \%) \\
4(40.0 \%) \\
4(0.0 \%) \\
1(10.0 \%) \\
0(0.0 \%) \\
\end{array}$ & 22.848 & 0.000 & $\mathrm{~S}$ \\
\hline $\begin{array}{l}\text { How noticeable the } \\
\text { clasps on anterior teeth }\end{array}$ & $\begin{array}{l}\text { 1.not at all } \\
\text { 2.a little difficult } \\
\text { 3.somehow difficult } \\
\text { 4.very difficult } \\
\text { 5.Extremely difficult }\end{array}$ & $\begin{array}{c}- \\
- \\
- \\
-\end{array}$ & $\begin{array}{c}6(30.0 \%) \\
7(35.0 \%) \\
4(20.0 \%) \\
3(15.0 \%) \\
0(0.0 \%)\end{array}$ & - & - & - \\
\hline Social/ family interaction & $\begin{array}{l}\text { 1.not at all } \\
\text { 2.a little difficult } \\
\text { 3.somehow difficult } \\
\text { 4.very difficult } \\
\text { 5.Extremely difficult }\end{array}$ & $\begin{array}{l}3(15.0 \%) \\
4(20.0 \%) \\
6(30.0 \%) \\
0(0.0 \%) \\
7(35.0 \%)\end{array}$ & $\begin{array}{c}10(50.0 \%) \\
4(20.0 \%) \\
3(15.0 \%) \\
0(10.0 \%) \\
0(5.0 \%)\end{array}$ & 11.69 & 0.02 & S \\
\hline
\end{tabular}


TABLE (5) Median, quartiles, mean and standard deviation of obturator functioning scale domains in group II before and after obturator fabrication.

\begin{tabular}{|c|c|c|c|c|c|c|}
\hline & & Pre & Post & Test value* & P-value & Sig. \\
\hline \multirow{3}{*}{ Insertion of obturator } & Median(Quartile 25th-75th) & & $1(1-2)$ & \multirow{3}{*}{-} & \multirow{3}{*}{ - } & \multirow{3}{*}{ - } \\
\hline & Mean \pm SD & - & $1.65 \pm 0.93$ & & & \\
\hline & Range & - & $1-4$ & & & \\
\hline \multirow{3}{*}{ Speech is understandable } & Median(Quartile 25th-75th) & $3(2-4)$ & $2(1-3)$ & \multirow{3}{*}{3.45} & \multirow{3}{*}{0.000} & \multirow{3}{*}{$\mathrm{S}$} \\
\hline & Mean \pm SD & $3.25 \pm 1.21$ & $1.90 \pm 0.97$ & & & \\
\hline & Range & $1-5$ & $1-4$ & & & \\
\hline \multirow{3}{*}{ Nasality of speech } & Median(Quartile 25th-75th) & $3(2-4)$ & $1(1-2)$ & \multirow{3}{*}{2.997} & \multirow{3}{*}{0.003} & \multirow{3}{*}{$S$} \\
\hline & Mean \pm SD & $3.0 \pm 1.45$ & $1.70 \pm 1.13$ & & & \\
\hline & Range & $1-5$ & $1-5$ & & & \\
\hline \multirow{3}{*}{ Pronounciation of words } & Median(Quartile 25th-75th) & $3(1.5-5)$ & $2(1-2.75)$ & \multirow{3}{*}{2.170} & \multirow{3}{*}{0.029} & \multirow{3}{*}{$S$} \\
\hline & Mean \pm SD & $3.20 \pm 1.54$ & $2.1 \pm 1.17$ & & & \\
\hline & Range & $1-5$ & $1-5$ & & & \\
\hline \multirow{3}{*}{ Talk in public } & Median(Quartile 25th-75th) & $4(3-4.75)$ & $2(1-2.75)$ & \multirow{3}{*}{3.225} & \multirow{3}{*}{0.000} & \multirow{3}{*}{$\mathrm{S}$} \\
\hline & Mean \pm SD & $3.55 \pm 1.28$ & $2 \pm 1.21$ & & & \\
\hline & Range & $1-5$ & $1-5$ & & & \\
\hline \multirow{3}{*}{$\begin{array}{l}\text { Voice different from } \\
\text { before surgery }\end{array}$} & Median(Quartile 25th-75th) & $3(2.25-5)$ & $1(1-2)$ & \multirow{3}{*}{2.67} & \multirow{3}{*}{0.008} & \\
\hline & Mean \pm SD & $3.35 \pm 1.35$ & $1.8 \pm 1.15$ & & & $\mathrm{~S}$ \\
\hline & Range & $1-5$ & $1-5$ & & & \\
\hline & Median(Quartile 25th-75th) & $4(2-5)$ & $1(1-2)$ & & & \\
\hline Leakage on swallowing & Mean \pm SD & $3.55 \pm 1.54$ & $1.85 \pm 0.93$ & 3.204 & 0.000 & S \\
\hline & Range & $1-5$ & $1-4$ & & & \\
\hline Jeakage on swallowing & Median(Quartile 25th-75th) & $4(3-5)$ & $2(1-3)$ & & & \\
\hline Leakage on swallowing & Mean \pm SD & $3.85 \pm 1.19$ & $2.3 \pm 1.23$ & 3.8 & 0.001 & $\mathrm{~S}$ \\
\hline & Range & $1-5$ & $1-5$ & & & \\
\hline & Median(Quartile 25th-75th) & $1(1-3)$ & $1(1-2)$ & & & \\
\hline Numbness of upper lip & Mean \pm SD & $2.15 \pm 1.6$ & $1.4 \pm 0.68$ & 1.91 & 0.056 & NS \\
\hline & Range & $1-5$ & $1-3$ & & & \\
\hline & Median(Quartile 25th-75th) & $4(3-5)$ & $1.5(1-2.75)$ & & & \\
\hline Upper lip looks funny & Mean \pm SD & $3.8 \pm 1.20$ & $2 \pm 1.3$ & 3.67 & 0.000 & $\mathrm{~S}$ \\
\hline & Range & $1-5$ & $1-5$ & & & \\
\hline & Median(Quartile 25th-75th) & $2(1-5)$ & $1(1-2)$ & & & \\
\hline Dryness of the mouth & Mean \pm SD & $2.60 \pm 1.67$ & $1.6 \pm 0.82$ & 2.865 & 0.042 & $\mathrm{~S}$ \\
\hline & Range & $1-5$ & $1-3$ & & & \\
\hline & Median(Quartile 25th-75th) & $4(3-5)$ & $2(1-3)$ & & & \\
\hline Chewing & Mean \pm SD & $3.7 \pm 1.30$ & $2.25 \pm 1.33$ & 3.63 & 0.00041 & $\mathrm{~S}$ \\
\hline & Range & $1-5$ & $1-5$ & & & \\
\hline & Median(Quartile 25th-75th) & $4(3.25-5)$ & $1(1-2.75)$ & & & \\
\hline Satisfaction with the look & Mean \pm SD & $3.95 \pm 1.28$ & $1.75 \pm 0.97$ & 3.423 & 0.000 & S \\
\hline & Range & $1-5$ & $1-4$ & & & \\
\hline & Median(Quartile 25th-75th) & & $2(1-3)$ & & & \\
\hline on anterior teeth & Mean \pm SD & - & $2.20 \pm 1.06$ & - & - & - \\
\hline & Range & - & $1-4$ & & & \\
\hline & Median(Quartile 25th-75th) & $3(2-5)$ & $1.5(1-3)$ & & & \\
\hline Social/ family interaction & Mean \pm SD & $3.20 \pm 1.51$ & $2 \pm 1.26$ & 2.234 & 0.026 & S \\
\hline & Range & $1-5$ & $1-5$ & & & \\
\hline
\end{tabular}


\pm 1.21 . As for the voice being different from before the maxillary resection the median was 3 and the mean was $3.35 \pm 1.35$ before obturator fabrication but after obturator fabrication the median was 1 and the mean was $1.8 \pm 1.15$. Before obturator fabrication, the median for leakage on swallowing fluids was 4 and the mean was $3.55 \pm 1.54$ and after obturator fabrication the median was 1 and the mean was $1.85 \pm 0.93$. The median for leakage on swallowing solids before obturator fabrication was 4 and the mean was $3.85 \pm 1.19$ and after obturator fabrication the median was 2 and the mean was 2.3 \pm 1.23 . The numbness of upper lip domain had a median 1 and a mean $2.15 \pm 1.6$ before obturator fabrication and a median 1 and a mean $1.4 \pm 0.68$ after wearing the obturator. For the upper lip looks funny, the median was 4 and the mean was $3.8 \pm 1.20$ before obturator fabrication while the median was 1.5 and the mean was $2 \pm 1.3$ after its fabrication.
The median for dryness of the mouth was 2 and the mean was $2.60 \pm 1.67$ before obturator fabrication and the median was 1 and the mean was $1.6 \pm 0.82$ while using the obturator. Chewing function had a median 4 and mean $3.7 \pm 1.30$ before obturator fabrication and a median 2 and a mean $2.25 \pm 1.33$ following the obturator fabrication. The obturator had a significant effect on the patients' satisfaction with their look as the median without the obturator was 4 and the mean was $3.95 \pm 1.28$ and with the obturator the median was 1 and the mean was 1.75 \pm 0.97 . The median for social and family interaction was 3 and the mean was $3.20 \pm 1.51$ before obturator fabrication and after fabrication the median was 1.5 and the mean was $2 \pm 1.26$

On comparing the effect of the obturator on the domains of the OFS in both groups using the Mannwhitney test, no statistical significant difference was found. Table (6)

TABLE (6) Median, quartiles, mean and standard deviation of obturator functioning scale domains in groups I and II after obturator fabrication.

\begin{tabular}{|c|c|c|c|c|}
\hline OFS domain & Group I $(n=20)$ & Group II (n=20) & Mann-Whitney test & p-value \\
\hline \multicolumn{5}{|l|}{ Insertion of obturator } \\
\hline Mean \pm SD & $1.60 \pm 0.68$ & $1.65 \pm 0.93$ & \multirow{3}{*}{-0.211} & \multirow{3}{*}{0.862} \\
\hline Median (Quartile 25th-75th) & $1.5(1-2)$ & $1(1-2)$ & & \\
\hline Range & $1-3$ & $1-4$ & & \\
\hline \multicolumn{5}{|l|}{ Speech is understandable } \\
\hline Mean \pm SD & $1.90 \pm 0.85$ & $1.90 \pm 0.97$ & \multirow{3}{*}{-0.115} & \multirow{3}{*}{0.925} \\
\hline Median (Quartile 25th-75th) & $2(1-3)$ & $2(1-3)$ & & \\
\hline Range & $1-3$ & $1-4$ & & \\
\hline \multicolumn{5}{|l|}{ Nasality of speech } \\
\hline Mean \pm SD & $1.60 \pm 0.82$ & $1.70 \pm 1.13$ & \multirow{3}{*}{0.000} & \multirow{3}{*}{1.000} \\
\hline Median (Quartile 25th-75th) & $1(1-2)$ & $1(1-2)$ & & \\
\hline Range & $1-3$ & $1-5$ & & \\
\hline \multicolumn{5}{|l|}{ Pronounciation of words } \\
\hline Mean \pm SD & $1.50 \pm 0.69$ & $2.10 \pm 1.17$ & \multirow{3}{*}{-1.761} & \multirow{3}{*}{0.108} \\
\hline Median (Quartile 25th-75th) & $1(1-2)$ & $2(1-2.75)$ & & \\
\hline Range & $1-3$ & $1-5$ & & \\
\hline
\end{tabular}




\begin{tabular}{|c|c|c|c|c|}
\hline OFS domain & Group I (n=20) & Group II (n=20) & Mann-Whitney test & p-value \\
\hline \multicolumn{5}{|l|}{ Talk in public } \\
\hline Mean \pm SD & $1.70 \pm 0.80$ & $2.00 \pm 1.21$ & \multirow{3}{*}{-0.553} & \multirow{3}{*}{0.620} \\
\hline Median (Quartile 25th-75th) & $1.5(1-2)$ & $2(1-2.75)$ & & \\
\hline Range & $1-3$ & $1-5$ & & \\
\hline \multicolumn{5}{|c|}{ Voice different from before surgery } \\
\hline Mean \pm SD & $1.45 \pm 0.76$ & $1.80 \pm 1.15$ & \multirow{3}{*}{-0.986} & \multirow{3}{*}{0.398} \\
\hline Median (Quartile 25th-75th) & $1(1-2)$ & $1(1-2)$ & & \\
\hline Range & $1-3$ & $1-5$ & & \\
\hline \multicolumn{5}{|l|}{ Leakage on swallowing fluids } \\
\hline Mean \pm SD & $1.70 \pm 0.92$ & $1.85 \pm 0.93$ & \multirow{3}{*}{-0.633} & \multirow{3}{*}{0.565} \\
\hline Median (Quartile 25th-75th) & $1.5(1-2)$ & $1(1-2)$ & & \\
\hline Range & $1-4$ & $1-4$ & & \\
\hline \multicolumn{5}{|l|}{ Leakage on swallowing solids } \\
\hline Mean \pm SD & $1.60 \pm 0.68$ & $2.30 \pm 1.23$ & \multirow{3}{*}{-1.8} & \multirow{3}{*}{0.068} \\
\hline Median (Quartile 25th-75th) & $1.5(1-2)$ & $2(1-3)$ & & \\
\hline Range & $1-3$ & $1-5$ & & \\
\hline \multicolumn{5}{|l|}{ Numbness of upper lip } \\
\hline Mean \pm SD & $1.25 \pm 0.44$ & $1.40 \pm 0.68$ & \multirow{3}{*}{-0.520} & \multirow{3}{*}{0.698} \\
\hline Median (Quartile 25th-75th) & $1(1-1.75)$ & $1(1-2)$ & & \\
\hline Range & $1-2$ & $1-3$ & & \\
\hline \multicolumn{5}{|l|}{ Upper lip looks funny } \\
\hline Mean \pm SD & $1.65 \pm 0.93$ & $2.00 \pm 1.34$ & \multirow{3}{*}{-0.802} & \multirow{3}{*}{0.478} \\
\hline Median (Quartile 25th-75th) & $1(1-3)$ & $1.5(1-2.75)$ & & \\
\hline Range & $1-3$ & $1-5$ & & \\
\hline \multicolumn{5}{|l|}{ Dryness of the mouth } \\
\hline Mean \pm SD & $1.45 \pm 0.69$ & $1.60 \pm 0.82$ & \multirow{3}{*}{-0.503} & \multirow{3}{*}{0.678} \\
\hline Median (Quartile 25th-75th) & $1(1-2)$ & $1(1-2)$ & & \\
\hline Range & $1-3$ & $1-3$ & & \\
\hline \multicolumn{5}{|l|}{ Chewing } \\
\hline Mean \pm SD & $2.30 \pm 1.45$ & $2.25 \pm 1.33$ & \multirow{3}{*}{-0.01} & \multirow{3}{*}{0.98} \\
\hline Median (Quartile 25th-75th) & $2(1-4)$ & 2. (1-3) & & \\
\hline Range & $1-5$ & $1-5$ & & \\
\hline Satisfaction with the look & & & & \\
\hline Mean \pm SD & $1.70 \pm 0.92$ & $1.75 \pm 0.97$ & & \\
\hline Median (Quartile 25th-75th) & $1.5(1-2)$ & $1(1-2.75)$ & -0.059 & 0.968 \\
\hline Range & $1-4$ & $1-4$ & & \\
\hline How noticeable the clasps on & & & & \\
\hline Mean \pm SD & $2.25 \pm 1.12$ & $2.20 \pm 1.06$ & & \\
\hline Median (Quartile 25th-75th) & $2(1-3)$ & $2(1-3)$ & -0.099 & 0.925 \\
\hline Range & $1-4$ & $1-4$ & & \\
\hline Social/ family interaction & & & & \\
\hline Mean \pm SD & $1.50 \pm 0.51$ & $2.00 \pm 1.26$ & & \\
\hline Median (Quartile 25th-75th) & $1.5(1-2)$ & $1.5(1-3)$ & -0.890 & 0.429 \\
\hline Range & $1-2$ & $1-5$ & & \\
\hline
\end{tabular}




\section{DISCUSSION}

The relatively small sample size was due to the exacting nature of the inclusion criteria and the rarity of studies like this in our environment. Patients with history of radiotherapy were excluded to avoid the negative sequalae as trismus and limitations of mandibular movement that may affect the results of this study. Radiotherapy induced more selfreported oral and swallowing problems in one study. This was attributed to xerostomia and stiffness that resulted in unreliable quality of life outcomes. ${ }^{(11,12)}$

A good obturator contributes to better quality of life and rehabilitation of patients with maxillary defects using well designed obturator can be an appropriate and non-invasive means of treatment. ${ }^{(13)}$

One piece conventional PMMA obturators require repeated adjustments and cause discomfort to the participants in the earlier stages of their rehabilitation. However, the insertion and removal of one-piece obturator in large maxillary defects with or without trismus is difficult. In such cases, the fabrication of a two-piece obturator, which has a bulb component and a maxillary plate overcomes the problem. ${ }^{(14)}$

Bulbs can be made from silicone based material. Silicone provides number of advantages as being nontoxic, resilient, easy to handle; and well tolerated by intraoral tissues. The softness and resiliency of the silicone materials enable it to engage undercuts within the defects, thus providing retention, adapatation and stability of the prosthesis. The flexibility of the material allows it to be removed from the defect site without injuring the soft tissues. ${ }^{(15)}$

The silicone hollow bulb flex or bend easily during insertion and removal, has intimate contact with the mucosa, and anchors the obturator in the smallest defect undercuts, thus drastically improving the retention of the obturator. It also provides a cushioning effect, patient comfort, an impenetrable seal preventing the entry of the liquid into nasal cavity, improved communication, inevitably increasing patient satisfaction, function, and an enhanced quality of life. ${ }^{(16,17,18)}$

Moreover, rehabiliatation of maxillary defects with two piece maxillary obturators facilitates easy examination of underlying tissues, recreation of the anatomic barrier between the oral and nasal cavities and restoration of the function and esthetics. Thus, it adds to the quality of life. ${ }^{(19)}$ Hollowing of the obturators in both groups was done to minimize the effect of the weight on the stability and the retention of the obturator. ${ }^{(17,20)}$

The WHO defines quality of life as the individual's perception of their position in life in relation to their goals, expectations, standards, and concerns. ${ }^{(21)}$ The OFS was developed at Memorial Sloan Kettering Cancer Center as a means of assessing the selfreported functioning of an obturator. ${ }^{(10)}$ The OFS questionnaires have been validated and used by other investigators. ${ }^{(22)}$ Patients were evaluated three months after obturator insertion to allow for the stimulatory effect of the obturator on the oral cavity and to enhance neuromuscular adaptation. ${ }^{(13,23,24)}$

The resulting oro-nasal communication after resection leads to hypernasal speech, low speech intelligibility, nasal regurgitation of food and liquids due to incomplete separation between the nasal and oral cavity, improper mastication, and disfigurement of facial appearance. Thus, the social behavior and quality of life (QoL) will be adversely affected. ${ }^{(18,19,25,26)}$

Results of this study show significant improvement in the domains of OFS in each group before and after obturator fabrication. However, there was no statistical significant difference between both types of the obturators on the OFS domains.

The significant increase in chewing ability and the highly significant enhancement of food leakage during swallowing in both groups may be due to the separation of the oral and nasal cavities allowing 
adequate deglutition and articulation. Moreover, the improved retention obtained from the silicone bulb of these obturators may have contributed to this improvement in group I. Because these obturators have resilient silicone surfaces they can be made to contact greater amounts of defect tissue without the risk of damage. ${ }^{(27)}$

Further study that evaluated chewing function with maxillary obturators using the mixing ability test revealed significant improved chewing function while using the obturator in comparison to chewing in its absence. Same study also showed that mastication after obturator reconstruction of a maxillectomy defect is comparable to mastication with full dentures. ${ }^{(12)}$

Another study evaluated chewing function using the sieve test and showed that chewing performance was improved using the obturator as it was not significantly different when compared with dentulous or removable partial/complete denture wearer, The same study also assessed swallowing function and found significant improvement in swallowing ability and also significantly reduced drinking time in maxillectomy patients while using an obturator. The reason of significant improvement while drinking with the obturator was attributed to the closure of oro-antral communication of the defect. ${ }^{(28)}$

Further study evaluated occlusal reflections using the computerized occlusal analysis the T-SCAN 8 system and indicated normal occluso-articulatory relations and confirmed the statement that the even distribution of masticatory pressure significantly improves nutrition. ${ }^{(29)}$ Another study showed that patients had significantly better masticatory and oral function, in addition to lesser chewing difficulties while using their obturators when compared to not wearing it. ${ }^{(30)}$

The speech of the patients was unintelligible after surgery; this was due to nasalance and misarticulations resulting from surgical resection of the palate. Post-maxillectomy speech disorders result from the distortion of oronasal resonance balance and tongue to palate contacts .Previous studies also showed that the speech becomes unintelligible following maxillectomy. ${ }^{(31,32)}$

Significant improvement in the domains as voice not different from before maxillary resection, nasality of speech, ability to talk in public, pronouncation of words, and speech being understandable was also reported by several studies. ${ }^{(27)}$ This may be due to the simulated effect of the obturator to the functional anatomy of hard palate and separation of the oral and nasal cavities with improved resonance to the speech. The resilience of these obturators is also likely to reduce hypernasal speech making words more understandable and clearly pronounced. ${ }^{(33)}$

Furthermore, oronasal separation achieved by prosthetic obturation of the defect is required for intelligible phonation and articulation since nasality of voice depends on the integrity of various resonating cavities. ${ }^{(31,34,35)}$ The results of further study found a successfully created barrier between the oral and nasal cavity using the "Oronasopneumotest" examination. The achieved effectiveness was a result of the implemented treatment method in which a two pieces maxillary obturator providing good retention and sufficient stability was used to close the defect. The prosthetic treatment with maxillary obturator allowed successful recovery of the lost speech. ${ }^{(29)}$

Significant decrease in dryness may be attributed to the greater likelihood of reduced salivation in individuals who have undergone maxillectomies. ${ }^{(36)}$ Regarding the look, patients were satisfied after wearing the obturator as it provides support for the facial tissues by replacing teeth as well as soft and hard tissues. ${ }^{(37)}$

The results of this study revealed that the maxillary obturator helped $50 \%$ of the patients with social interaction without any problems at all and $50 \%$ with little problems. On the other hand, $10 \%$ of the patients only were able to interact socially before obturator fabrication as shown in other 
studies. ${ }^{(10)}$ This is may be due to the several advantages can be achieved with obturators such as replacing teeth as well as soft and hard tissues, allowing approximately normal speaking and swallowing for the patient. In addition, it prevents fluids leakage and communication between nasal and oral cavities. Moreover, it enhances the facial appearance as it provides support for the facial tissues. ${ }^{(37)}$

Significant improvement in the domains of the obturator functioning scale following the obturator fabrication was also supported by further studies. These results support the findings that good obturator function is associated with a better quality of life. ${ }^{(26,38)}$

\section{CONCLUSION}

Maxillary obturators fabricated following maxillary resections appear to improve chewing ability, speech, social interaction in addition to less leakage on swallowing. So, the quality of life can be improved using a maxillary obturator after maxillectomy operation. This treatment might be an alternative to surgical reconstruction after maxillectomy especially in medically compromised and old patients.

\section{Study limitations}

Limitations of this study include the number of patients having the required inclusion criteria with subsequent absence of further patient groups having another means of retention for maxillary obturator for further comparison. Moreover, the included patients were restricted to Brown Class II A, so the effect of both types of the obturator on more severe classes as III and IV was not evaluated. Furthermore, during post insertion follow up the questionnaire was filled in once after 3 months meanwhile, quality of life 1 year later has been shown to be a good indicator of long term quality of life as suggested by some papers.

\section{Research recommendations}

Another retentive modalities for maxillary obturators as attachments should be investigated. Furthermore, longer than 3 months (1 year) follow up should be adopted. Regarding the silicone bulb, a further research can be employed in patients with bilateral total maxillectomy to evaluate its effect in comparison to conventional acrylic bulb obturators.

\section{REFERENCES}

1. Drugan C, Leary S, Mellor T, et al.: Head and neck cancer in the south west of England, Hampshire,and the Isle of Wight: trends in survival. Br J OralMaxillofac. Surg , 51: 19,2013

2. Newton JT, Fiske J, Foote O, et al.: Preliminary study of the impact of loss of part of the face and its prosthetic restoration. J Prosthet Dent, 82:585,1999.

3. Lethaus B, Lie N, de Beer F, et al.: Surgical and prosthetic reconsiderations in patients with maxillectomy. J Oral Rehabil, 37: 138, 2010.

4. Ariani N, Visser A, van Oort RP, et al.:Current state of craniofacial prosthetic rehabilitation.Int J Prosthodont,26:57, 2013.

5. Dingman C, Hegedus PD, Likes C, et L.: Coordinated, multidisciplinary approach to caring for the patient with head and neck cancer. J Support Oncol, 6: 125;2008.

6. O'Fearraigh: Review of methods used in the reconstructionand rehabilitation of the maxillofacial region. J Iran Dent Assoc, 56: 32;2010.

7. Desjardins RP, Laney WR.: Prosthetic rehabilitation after cancer resection in the head and neck. Surg Clin North Am, 57: $809 ; 1977$.

8. Ikusika F, Dosumu O, Deborah M. et al.: Effect of resilient lining of obturator bulbs on patients with maxillectomies. J prosthet dent, 116:932; 2016.

9. Murray CG.: A resilient lining material for the retention of maxillofacial prosthesis. J Prosthet Dent,42; 53;1979.

10. Kornblith AB, Zlotolow IM, Gooen J, et al.: Quality of life of maxillectomy patients using an obturator prosthesis Head Neck, 18: 323,1996. 
11. Borggreven PA, Aaronson NK, Verdonck-deLeeuw IM, et al.: Quality of life after surgicaltreatment for oral and oropharyngeal cancer:a prospective longitudinal assessment of patients reconstructed by a microvascularflap. Oral Oncol, 43:1034-42.27;2007.

12. Kreeft AM, Krap M, Wismeijer D et al.:Oral function after maxillectomy and reconstruction with an obturator. Int $\mathrm{J}$ Oral Maxillofac Surg, 41: 1387-1392;2012.

13. Ali MM, Khalifa $\mathrm{N}$ and Alhajj MN: Quality of life and problems associated with obturators of patients with maxillectomies. Head \& Face Med, 14;2-9,2018.

14. Thirumurthy V. Ramasamy, Chandra1 J: An innovative sectional silicone obturator in a patient with partial maxillectomy J Indian Prosthodont Soc, 20 :115-119;2020.

15. Mitra A, Choudhary S, Garg H et al.: Maxillofacial prosthetic materials- an inclination towards silicones. J Clin Diagn Res,8: 08-13;2014.

16. Rilo B, Dasilva L, Ferros I et al.: A hollow-bulb interim obturator for maxillary resection. A case report. J Oral Rehabil,6: 234,2005 .

17. Brown KE: Peripheral consideration in improving obturator retention. J Prosthet Dent, 81: 176;1969.

18. Punjabi AR,Mistry G,Shetty O et al.: Maxillary hollow-bulb obturator: A paradigm shift. J Indian Prosthodont Soc, 19: 74-78, 2019.

19. Dholam KP, Sadashiva KM, Bhirangi PP.: Rehabilitation of large maxillary defect with two-piece maxillary obturators.J Can Res, 1:11;664, 2015

20. Singh K, Kumar N,Gupta N, ET AL.: Modification of existed prosthesis into a flexible wall hollow bulb obturator by permanent silicone soft liner for a hemimaxillectomy patient with restricted mouth opening. J prosth research, 59: 205-209; 2015.

21. Sharaf MY, \& Ibrahim SI, Eskander AE et al.:Prosthetic versus surgical rehabilitation in patients with maxillary defect regarding the quality of life: systematic review. Oral Maxillofac Surg, 22:1-11; 2018.

22. Wang F, Huang W, Zhang $\mathrm{C}$ et al.: Functional outcome and quality of life after a maxillectomy: a comparison between an implant supported obturator and implant supported fixed prostheses in a free vascularized flap. Clin. Oral Impl Res, 1: 1-7: 2016.
23. Jacob RF, Weber RS, King GE et al.: Whole salivary flow rates following submandibular gland resection. Head Neck, 5:242-247;1996.

24. Krausch-hofmann S, cuypers 1, ivanova a et al.: predictors of patient satisfaction with removable denture renewal: a pilot study. J prosthodont, 27: 509-516; 2016

25. Depprich R, Naujoks C, Lind D et al.: Evaluation of the quality of life of patients with maxillofacial defects after prosthodontic therapy with obturator prostheses. Int J Oral Maxillofac Surg, 40:71-79;2011.

26. Irish J, Sandhu N, Simpson C et al.: Quality of life in patients with maxillectomy prostheses. Head Neck :813821.2009.

27. Chena C, Rena W, Gaob L et al.: Function of obturator prosthesis after maxillectomy and prosthetic obturator rehabilitation. Braz J Otorhinolaryngol, 82:177---183;2016.

28. Vero1 N, Mishra1 N,Pratap B et al.: Assessment of swallowing and masticatory performance in obturator wearers: a clinical study. J Adv Prosthodont, 7:8-14;2015.

29. Gerdzhikov I, Dimova M, Georgiev T: Efficiency of prosthetic treatment with post resection prostheses with solid substitute part. J of IMAB, 22: 3;2016.

30. Buurman JM, Caroline M, Speksnijder et al.: Masticatory performance and oral health-related quality of life in edentulous maxillectomy patients. Clin Oral Impl Res, $00: 1-12 ; 2020$.

31. Kumar P, Jain V, Thakar A, et al: Effect of varying bulb height on articulation and nasalance in maxillectomy patients with hollow bulb obturator. J Prosthodont Res, 57:200-205;2013.

32. Kumar P,Jain V,Thakar A: Speech Rehabilitation of Maxillectomy Patients with Hollow Bulb Obturator Indian. J Palliat Care,18: 207-212;2018.

33. Choudhury M, Shanmuganathan N,Padmanabhan TV et al.: Rehabilitation of post surgical maxillectomy defects using interim obturators - a case series indian. J Surg Oncol, 4: 315-320; 2014.

34. Tripathi A, MNAMS F, Gupta A et al.: Effect of Prosthodontic Rehabilitation of Maxillary Defects on Hypernasality of Speech. J Prosthodont, 25: 202-206;2016. 
35. El-Maghraby R, El-Didi LM., Al-Shimy A. et al.: The speech outcome of definitive obturators constructed usingtwo different impression techniques.The Egyptian Journal of Otolaryngology, 32:61-66;2016.

36. Oluwafeyisayo F, Ikusika, Oluwole O. et al.: Effect of resilient lining of obturator bulbs on patients with maxillectomies. J Prosthet Dent, 116: 932-936;2016.
37. Alhajj MN, Ismail IA, Khalifa N: Maxillary obturator prosthesis for a hemimaxillectomy patient: a clinical case report. Saudi. J Dent Res. 7:153-9;2016.

38. Seignemartin CP,Miranda ME, Gualberto C et al.: Understandability of Speech Predicts Quality of Life Among Maxillectomy Patients Restored With Obturator Prosthesis .J Oral Maxillofac Surg, 73:2040-2048, 2015. 